D. CANTillo, M. BAGHBAnZADEh, C. O. KAPPE* (KARL-FRAnZENS-University, GRAZ, AUSTRIA)

In Situ Generated Iron Oxide Nanocrystals as Efficient and Selective Catalysts for the Reduction of Nitroarenes

Using a Continuous Flow Method

Angew. Chem. Int. Ed. 2012, 51, 10190-10193.

\title{
Reduction of Nitroarenes Using In Situ Generated Iron Oxide Nanocrystals
}

Gategory

Polymer-Supported

Synthesis

Key words

iron

nanoparticles

nitroarenes

reduction

flow reaction

Reduction of nitroarenes using the batch system:<smiles>O=[N+]([O-])c1c[c-]ccc1</smiles>

Selected examples:<smiles>Nc1ccccc1</smiles>

$2 \min , 99 \%$ yield<smiles>COc1ccc(N)cc1</smiles>

6 min, $99 \%$ yield<smiles>Nc1ccc(Cl)cc1</smiles>

2 min, 99\% yield<smiles>COC(=O)c1cccc(N)c1</smiles>

6 min, $95 \%$ yield
$\mathrm{Fe}(\mathrm{acac})_{3}(0.25 \mathrm{~mol} \%)$

$\mathrm{N}_{2} \mathrm{H}_{4} \cdot \mathrm{H}_{2} \mathrm{O}$ (1.2 equiv)

$$
\mathrm{MeOH}
$$

$\mathrm{MW}, 150^{\circ} \mathrm{C}, 2-8 \mathrm{~min}$<smiles>Nc1ccc(Cl)c(Cl)c1</smiles>

2 min, 99\% yield<smiles>CC(=O)Nc1ccc(N)cc1</smiles>

$4 \mathrm{~min}, 99 \%$ yield<smiles>Nc1c[c-]ccc1</smiles>

(eq. 1)

20 examples 95-99\% yield

Continuous-flow reduction of nitroarenes:<smiles>[R]c1ccccc1[N+](=O)[O-]</smiles>

ca. $1.0 \mathrm{M}$ solution in $\mathrm{MeOH}$ (1.2 $\mathrm{M} \mathrm{N}_{2} \mathrm{H}_{4} \cdot \mathrm{H}_{2} \mathrm{O}, 2.5 \mathrm{mM}$ cat.)<smiles>Nc1ccccc1</smiles>

$$
\begin{gathered}
6 \mathrm{~mL} / \mathrm{min}, 150^{\circ} \mathrm{C} \\
\text { residence time: } 1.6 \mathrm{~min} \\
96 \% \text { yield }
\end{gathered}
$$

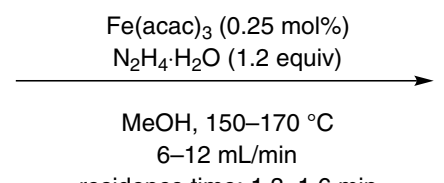

residence time: $1.3-1.6 \mathrm{~min}$<smiles>Nc1ccccc1Cl</smiles>

$12 \mathrm{~mL} / \mathrm{min}, 170{ }^{\circ} \mathrm{C}$ residence time: $1.3 \mathrm{~min}$ $95 \%$ yield<smiles>Nc1ccccc1O</smiles><smiles>Nc1cc(O)ccc1Cl</smiles>

$8 \mathrm{~min}, 99 \%$ yield

4 min, $99 \%$ yield<smiles>Nc1ccc2ncccc2c1</smiles><smiles>Nc1ccccc1-c1ccc(Cl)cc1</smiles>

$2 \mathrm{~min}, 99 \%$ yield
Significance: Iron oxide nanocrystals, generated in situ from $\mathrm{Fe}(\mathrm{acac})_{3}$ and hydrazine hydrate, catalyzed the reduction of nitroarenes with hydrazine hydrate under microwave conditions to give the corresponding anilines in 95-99\% yield (20 examples, eq. 1). In the reduction of nitrobenzene to aniline using the batch system, the catalyst was magnetically separated from the reaction mixture and reused seven times.
Comment: The reduction of nitroarenes was also performed using a continuous-flow system to afford the anilines in 95-97\% yield (eq. 2). The in situ generated iron oxide nanoparticles were characterized by XRD and HRTEM analyses. ICP-MS showed $7.9 \%$ iron leaching from the catalyst during the reduction using the batch system.

SYNFACTS Contributors: Yasuhiro Uozumi, Fumie Sakurai 